\title{
Population Dynamics of Saddle Grunt Fish, Pomadasys maculatus (Bloch, 1793) from Pakistani Waters
}

\author{
Abdul Baset ${ }^{1,2}$, Qun Liu ${ }^{2, ~ *}$, Baochao Liao², Abdul Waris ${ }^{3}$, Imtiaz Ahmad $^{4}$, Han Yanan ${ }^{2}$, \\ Zhang Qingqing ${ }^{2}$ \\ ${ }^{1}$ Department of Zoology, Bacha Khan University, Charsadda, Pakistan \\ ${ }^{2}$ College of Fisheries, Ocean University of China, Qingdao, China \\ ${ }^{3}$ Department of Biotechnology, Quaid-e-Azam University, Islamabad, Pakistan \\ ${ }^{4}$ Department of Botany, Bacha Khan University, Charsadda, Pakistan
}

Email address:

qunliu@ouc.edu.cn (Qun Liu)

${ }^{*}$ Corresponding author

\section{To cite this article:}

Abdul Baset, Qun Liu, Baochao Liao, Abdul Waris, Imtiaz Ahmad, Han Yanan, Zhang Qingqing. Population Dynamics of Saddle Grunt Fish, Pomadasys maculatus (Bloch, 1793) from Pakistani Waters. Bioprocess Engineering. Vol. 4, No. 1, 2020, pp. 1-8.

doi: $10.11648 /$ j.be.20200401.11

Received: December 6, 2019; Accepted: January 2, 2020; Published: February 4, 2020

\begin{abstract}
Length frequency data of Pomadasys maculatus (Bloch, 1793) was collected during 2012 and 2014 from Pakistan waters. Total 1387 fish individuals (pooled) were collected ranging from 7-22 cm (total length). Weight ranging 5-105 g. The data were analyzed for the estimation of population dynamics. The power coefficient of 2.532 in 2012 and 2.560 in 2014. The von Bertalanffy growth parameters of $23.10 \mathrm{~cm}\left(\mathrm{~L}_{\infty}\right), 0.480 \mathrm{year}^{-1}(\mathrm{~K})$ for 2012 and $23.10 \mathrm{~cm}\left(\mathrm{~L}_{\infty}\right), 0.570$ year ${ }^{-1}(\mathrm{~K})$ for 2014 , were calculated by ELEFAN method. The $Z$ was 2.06 years $^{-1}$ for 2012 and 2.07 year $^{-1}$ for 2014 . The M) was 1.16 year $^{-1}$ for 2012 and 1.30 year $^{-1}$ for 2014 calculated with Pauly's equation. Therefore, the $F$ was 0.9 years $^{-1}$ in 2012 and 0.77 years ${ }^{-1}$ in 2014 . The exploitation ratio was estimated to be 0.43 and 0.32 respectively. The YPRA (yield-per-recruit analysis) indicated that the estimated $F_{\max }$ was 1 for both years, when tc was $1 . F_{\text {current }}$ was 0.9 and 0.77 (for 2012 and 2014 respectively) which was less than $\mathrm{F}_{\max }$. With Gulland method, the BRPs for the fishery $\left(F_{\text {opt }}\right)$ was estimated at 1.16 years $^{-1}$ and 1.30 years ${ }^{-1}$ respectively, higher than current fish mortality. Accordingly, the Pomadasys maculatus fishery is in managing the condition in Pakistani waters.
\end{abstract}

Keywords: Pakistan, Pomadasys maculatus, Length-weight Relationship (LWR), Mortality, Growth

\section{Introduction}

Pakistan is endowed with marine fisheries resources which not only supply the valuable animal protein, but also contribute to the national economy of the country, especially in the human development and employment [1]. Pakistan exports fish and fisheries products in the form of chilled, frozen, cured and canned to 47 countries of the world [2]. The exported fish and fishery products was 155671 metric tons valued at 367.472 USD during 2013-2014 [2].

Fishes belong to Haemulidae (Grunters) are average sized, usually found in coastal inshore waters. They are also found in the zones of coral reefs, weedy or muddy waters. Grunts are commonly marine and brackish water inhabiting fishes of the Indian, Pacific and Atlantic regions that are rarely found in fresh water [3]. The family Haemulidae (grunts) comprises 19 genera and about 133 species distributed throughout the world [4]. Several species belonging to this family are common in Pakistan. Genus Pomadasys consist of 35 species [4] but only 9 species have been reported in Pakistani waters [3].

Saddle grunter locally called Dhoter is one of the commercially important fish of Pakistan. Their flesh is not easily perishable and thus it is considered as a valuable food, marketed both fresh and salt dried. Its maximum size is 50 $\mathrm{cm}$ in Pakistani waters while the common length is about 15 $\mathrm{cm}$. Their major feed sources include crustaceans and fishes. $[3,5]$. 
Only few reports have been made on $P$. maculatus in Pakistan such as on the Fecundity and sex ratio [6]; on the sex ratio, Gonadosomatic index and stages of gonadal development [7] and on study of some morphometric characteristics [7]. The present work was designed to evaluate the population dynamics of $P$. maculatus from Pakistani waters.

\section{Material and Methods}

A total of 1387individuals (675 were collected during 6 surveying months of 2012, with 108 in February, 111 in April, 126 in June, 102 in August, 115 in October and113 in December while 712 fish samples during6 surveying months of 2014, with 121 in February, 124 in April, 135 in June, 106 in August, 113 in October and113 in December) of Pomadasys maculatus were collected and measured from the fishermen catches caught with handlines and traps at random, from the Karachi coast of Pakistan. The total length (TL) of each fish was taken to the closest $1.0 \mathrm{~cm}$ using measuring board. The weight (W) of each fish was /measured to the closest of $1.0 \mathrm{~g}$. The samples included both male and female.

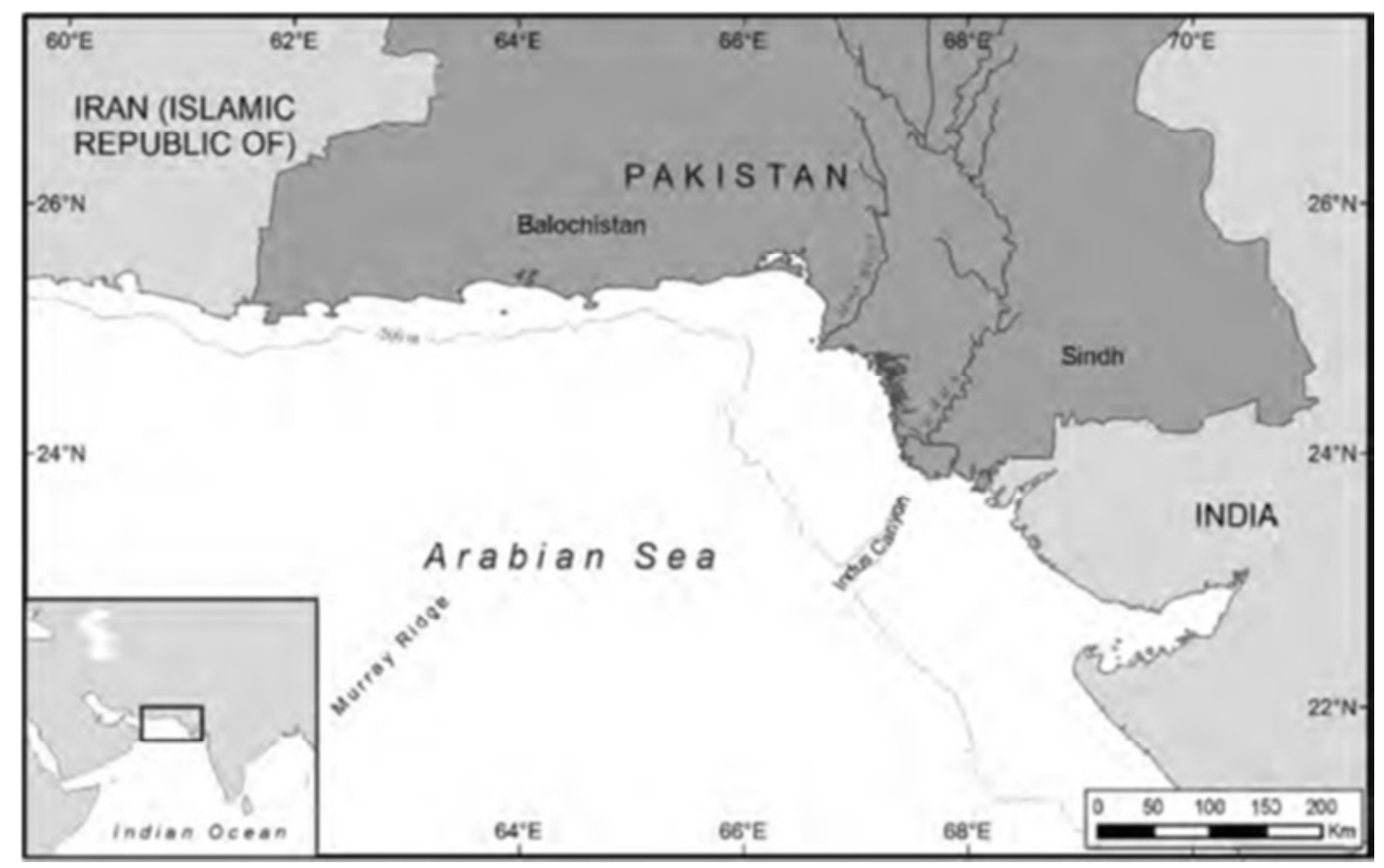

Figure 1. Map shows major landing sites along the Pakistan coast.

The length frequency data of $P$. maculatus during 2012 and 2014 was analyzed by the FiSAT-II package [8]. In this study, the following core population parameters such as BRPs, growth, growth performance index, mortality rate, virtual population analysis etc were estimated in the present study.

The weight $(\mathrm{W}, \mathrm{g})$ relationship to the length $(\mathrm{L}, \mathrm{cm}-\mathrm{TL})$ of $P$. maculatus was established using power equation [27]: $W=a L^{b}$. The parameters for growth of $P$. maculatus during 2012 and 2014 was calculated by using the von Bertalanffy equation for growth in length according to Haddon [9] is: $L t=L_{\infty}\left(1-\exp \left(-K\left(t-t_{0}\right)\right)\right)$, where $L_{t}, t, L_{\infty}, K$ and $t_{0}$ was the length at the predicted time, asymptotic length, growth coefficient and the hypothetical age respectively. Additional assessed rate of $t_{0}$ was acquired by the equation by Pauly [10] as: $\log _{10}\left(-t_{0}\right)=-0.3922-0.275 \log _{10} L_{\infty}-1.038 \log _{10} \mathrm{~K}$.

The instantaneous total mortality $(\mathrm{Z})$ for $P$. maculatus during 2012 and 2014, were estimated by the length converted catch curve (LCCC) method was used. Additional parameters of $\mathrm{M}$ and $\mathrm{F}$ were also calculated. The regression formula for $\mathrm{Z}$ is: $\mathrm{Ln}(\mathrm{Nt})=\mathrm{Ln}(\mathrm{N} 0)-\mathrm{Zt}$, where $\mathrm{Nt}$ is the population size at age $t$ and N0 is population size at 0 [10]. The equation by Pauly (1980) was used for natural mortality (M) from $\log _{10} M=0.0066-0.279 \log _{10} L_{\infty}+0.654 \log _{10} K+$
$0.4634 \log _{10} T$. Where $T=27^{\circ} \mathrm{C}$ was average annual sea surface temperature of Pakistani waters. The $F$ was assessed by $Z-M$. The exploitation ratio was got by $F / Z=F /(F+M)$. The Beverton and Holt's method can be used to estimate total annual mortality (Z) [11]: $Z=K \frac{L_{\infty}-\bar{L}_{L^{\prime}}}{\bar{L}_{L^{\prime}}-L^{\prime}}$ where $\bar{L}_{L^{\prime}}$ is the mean length of fish of length $L^{\prime}$ and larger where $L^{\prime}$ is a length such that all fish of that length and larger are fully selected by the fishery.

According to Sparre and Venema [12] VPA of $P$. maculatus during 2012 and 2014 from Pakistani waters was approved with the LWR parameters intercept $(a)$, slope $(b)$ and growth parameters values of $L_{\infty}, K$ and mortality parameters values of $M$ and $F$ to estimate the $F / L$ class. The value of $t_{0}$ was zero. $F_{o p t}=M$ was determined as the limit BRPs [25], for P. maculatus during 2012 and 2014 from Pakistani waters.

$$
Y_{w} / R=\mathrm{FW}_{\infty} e^{-M\left(t_{c}-t_{r}\right)} \sum_{n=0}^{3} \frac{\mathrm{Q}_{n} e^{-n K\left(t_{c}-t_{0}\right)}}{F+M+n K}\left(1-e^{-(F+M+n K)\left(t_{\lambda}-t_{c}\right)}\right)
$$


The model used by Beverton and Holt [11] incorporated into the FAO FiSAT-II program [9] with the formula relative yield per recruitment $(Y / R)$ values as a function of exploitation ratio (E) of P. maculatus during 2012 and 2014 from Pakistani waters were estimated [13].

The appraised values of $L_{\infty}$ (asymptotic length) and $K$ (growth constant) P. maculatus during 2012 and 2014 were used to calculate the $\Phi^{\prime}$. Following equations by Pauly and Munro [14] $\Phi^{\prime}=\log _{10} K+2 \log _{10} L_{\infty}$ and $\Phi=\log _{10} K+2 / 3$ $\log _{10} W_{\infty}$ were used.

\section{Results}

Overall 1387 individuals of $P$. maculatus were examined during this study in 2012 and 2014. The smallest recorded length was $7 \mathrm{~cm} /$ while the longest was $22 \mathrm{~cm}$. The dominant individuals were ranged from 12 to $16 \mathrm{~cm}$ in total length (TL) (Figures $2 \& 3$ ). Weights were measured from 5 to 105 g. The LWR of both sexes (male \& female) combined was: $\mathrm{W}=0.0522 \mathrm{x}^{2.5324}\left(R^{2}=0.978\right)$ for 2012 and $\mathrm{W}=0.0485 \mathrm{x}^{2.5605}$ $\left(R^{2}=0.979\right)$ (Figures $\left.2 \& 3\right)$ for 2014 .

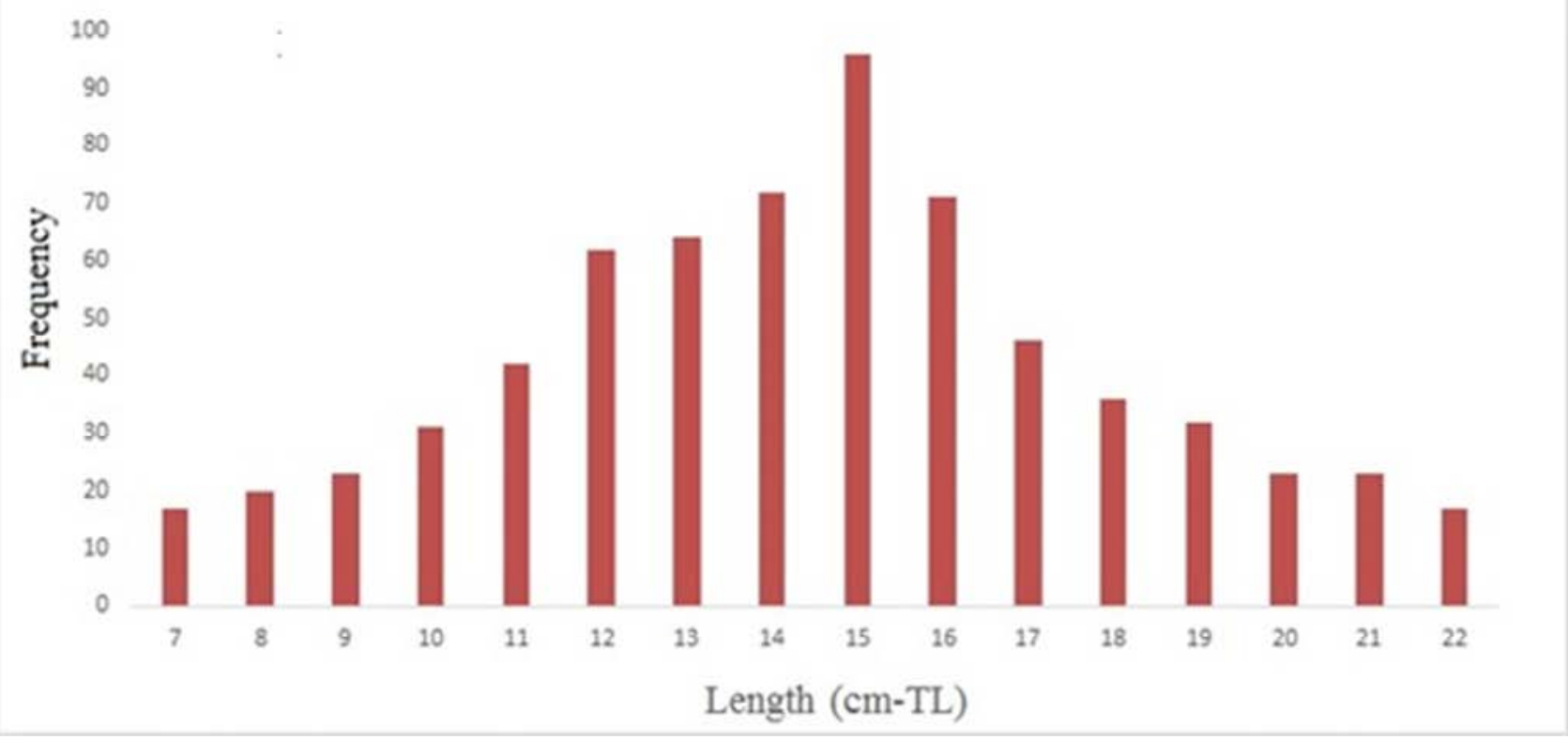

a

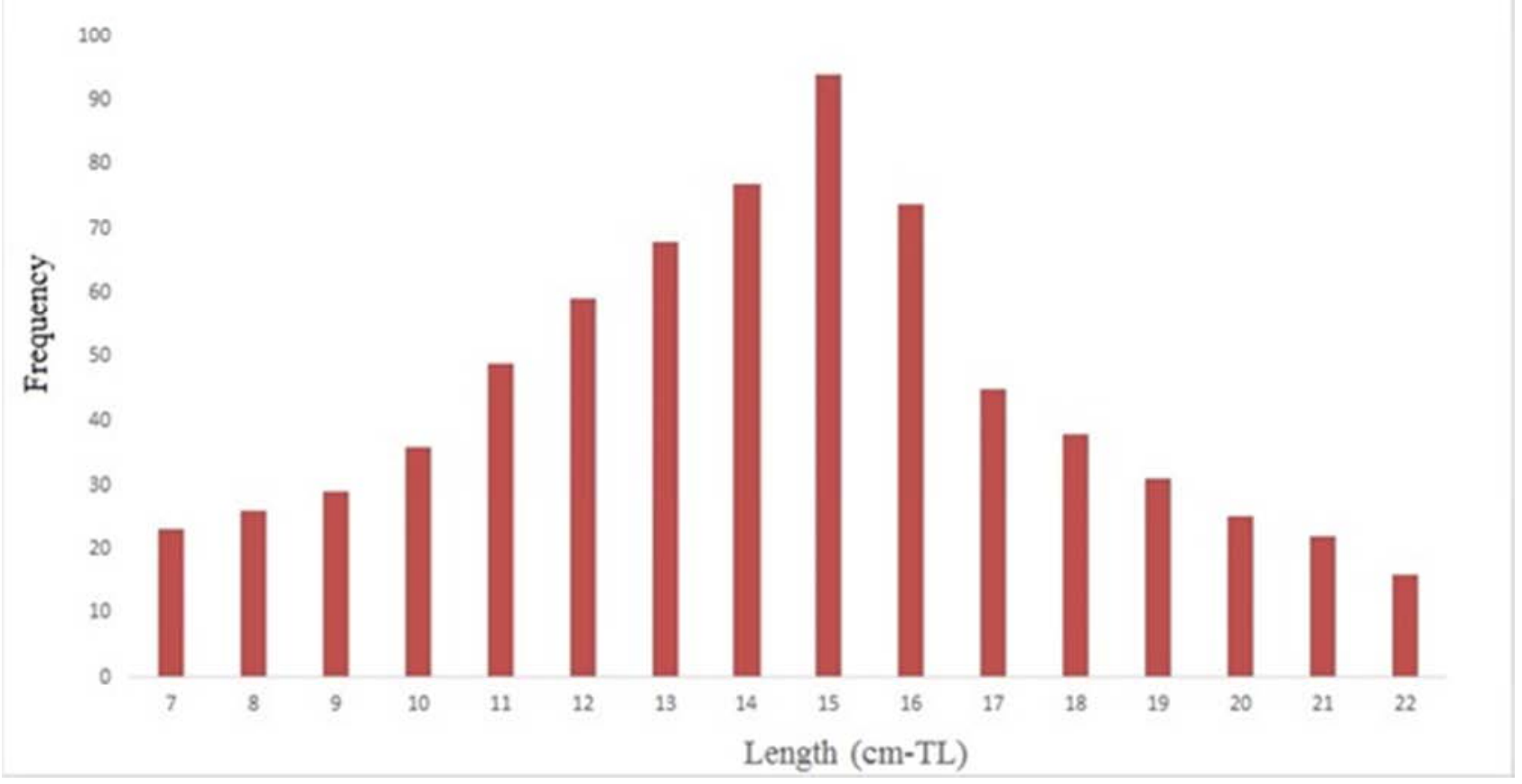

b

Figure 2. Length frequency distribution of P. maculatus from the Karachi coast of Pakistan, a \& b stand for 2012 and 2014 repectively. 
Growth parameters for $P$. maculatus were estimated by ELEFAN-I method, where $L_{\infty}=23.10$ (TL-cm) and 0.480 year $^{-1}$ for $K$ in 2012 and were $L_{\infty}=23.10(\mathrm{TL}-\mathrm{cm})$ and 0.570 year $^{-1}$ for $K$ for 2014 (Figure 4 ) with the goodness of fit at $\mathrm{Rn}=0.156$ for 2012 and $\mathrm{Rn}=0.101$ for 2014 . The $t_{0}$ values were calculated as -0.3659 for 2012 and -0.3061 for 2014 .

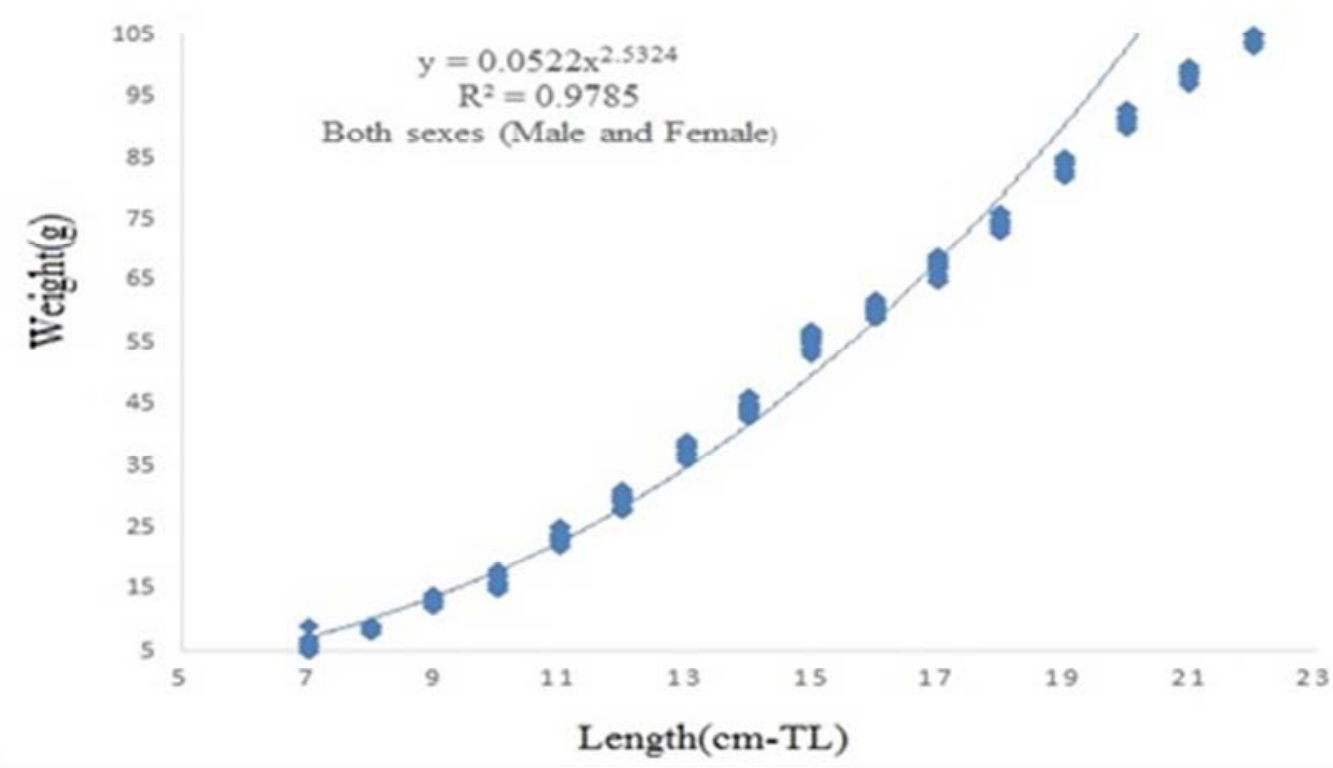

a

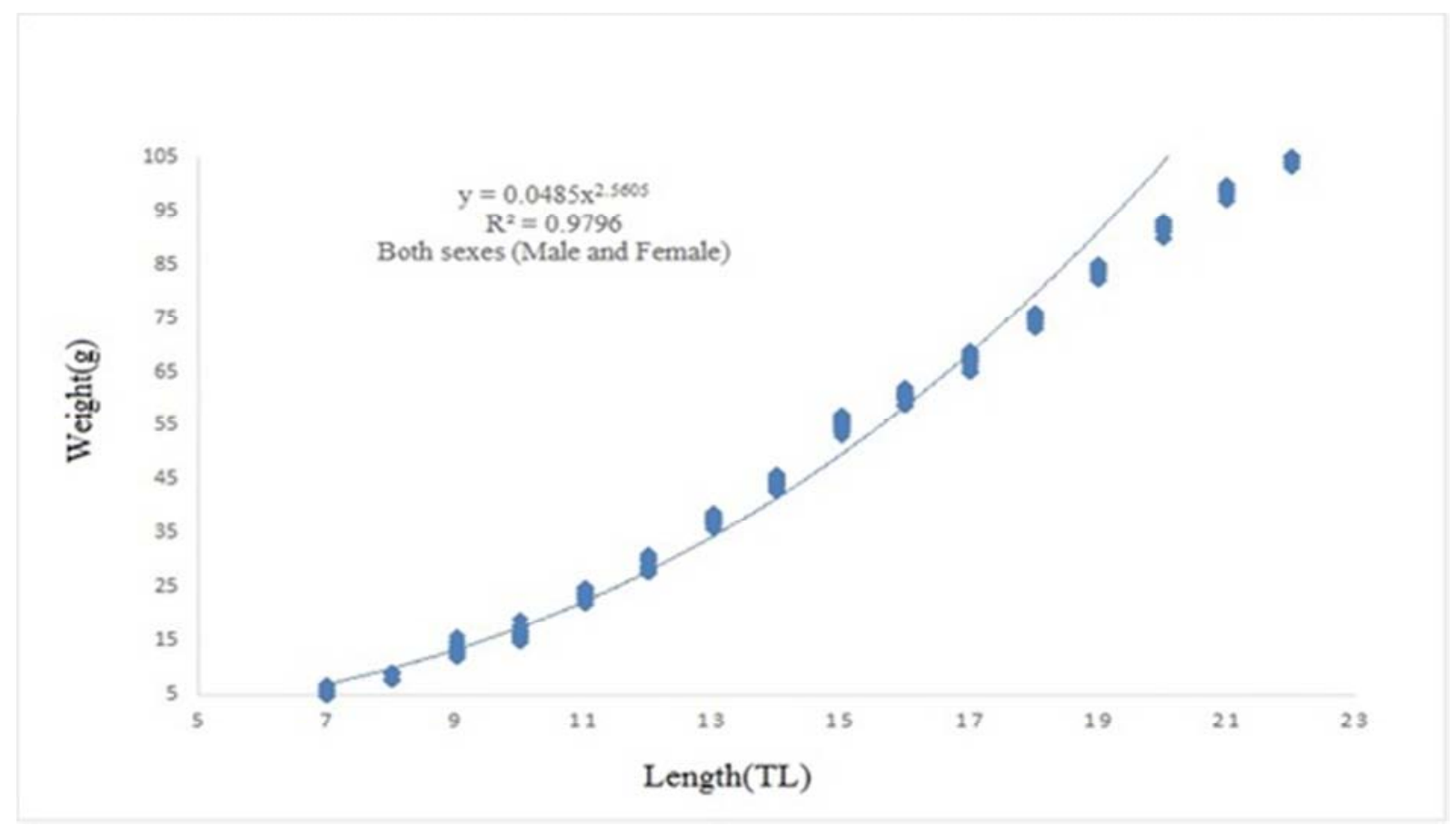

b

Figure 3. Length-weight relationship of P. maculates (both sexes combined), length and weight ranging from 10 to $24 \mathrm{~cm}$ (TL) and 9 to $110 \mathrm{~g}$ respectively, a \& $b$ stand for 2012 and 2014 respectively.

Applying VBGF $L_{\infty}$, and $K$ and using the LCCC (length converted catch curve) analysis, $Z=2.06$ (1.56-2.56) year ${ }^{-1}$ (Figure 5a) for 2012 and 2.07 (1.61-2.52) year $^{-1}$ (Figure 5b) for 2014. $M=1.16$ year $^{-1}$ (with $L_{\infty}=23.10 \mathrm{~cm}, K=0.480$ year $^{-1}$ and average annual sea surface temperature $27^{\circ} \mathrm{C}$ ) for 2012 and $M=1.30$ year $^{-1}$ (with $L_{\infty}=23.10 \mathrm{~cm}, K=0.570$ year $^{-1}$ ) for 2014 using Pauly (1980) equation. $F$ was calculated as $Z$ $M=0.9$ year $^{-1}$ in 2012 and 0.77 years $^{-1}$ in 2014 . While the $E$ was calculated from $F / Z=0.43$ and 0.32 for 2012 and 2014 respectively. 


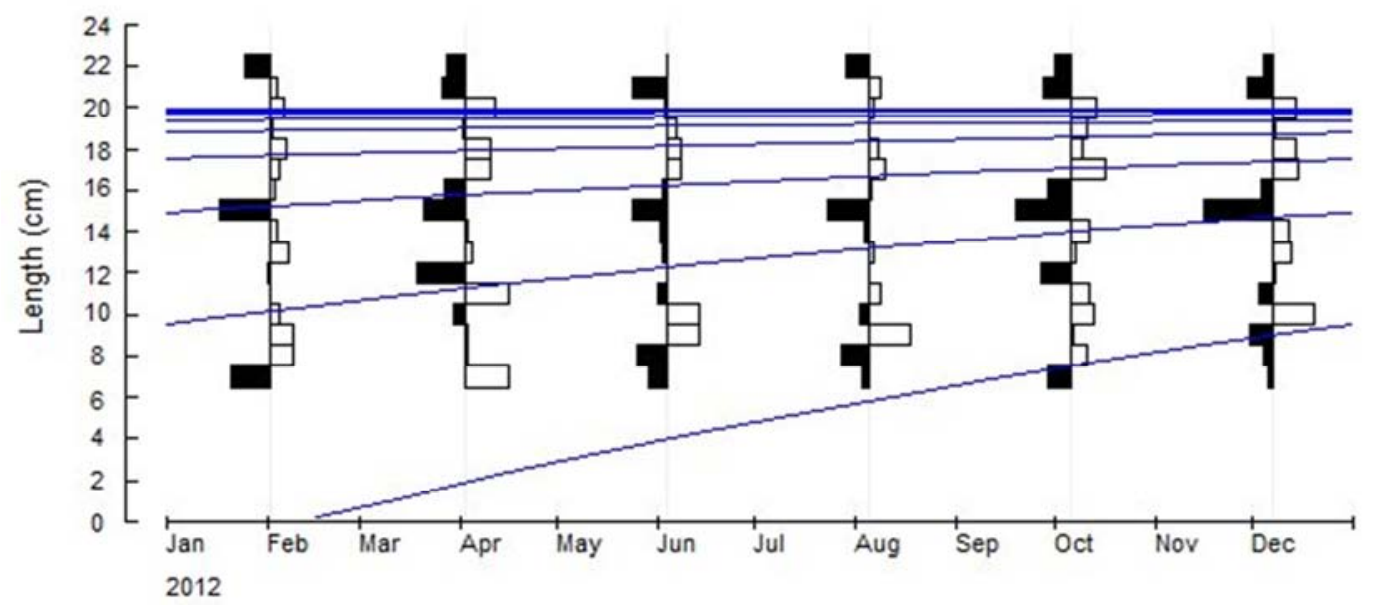

a

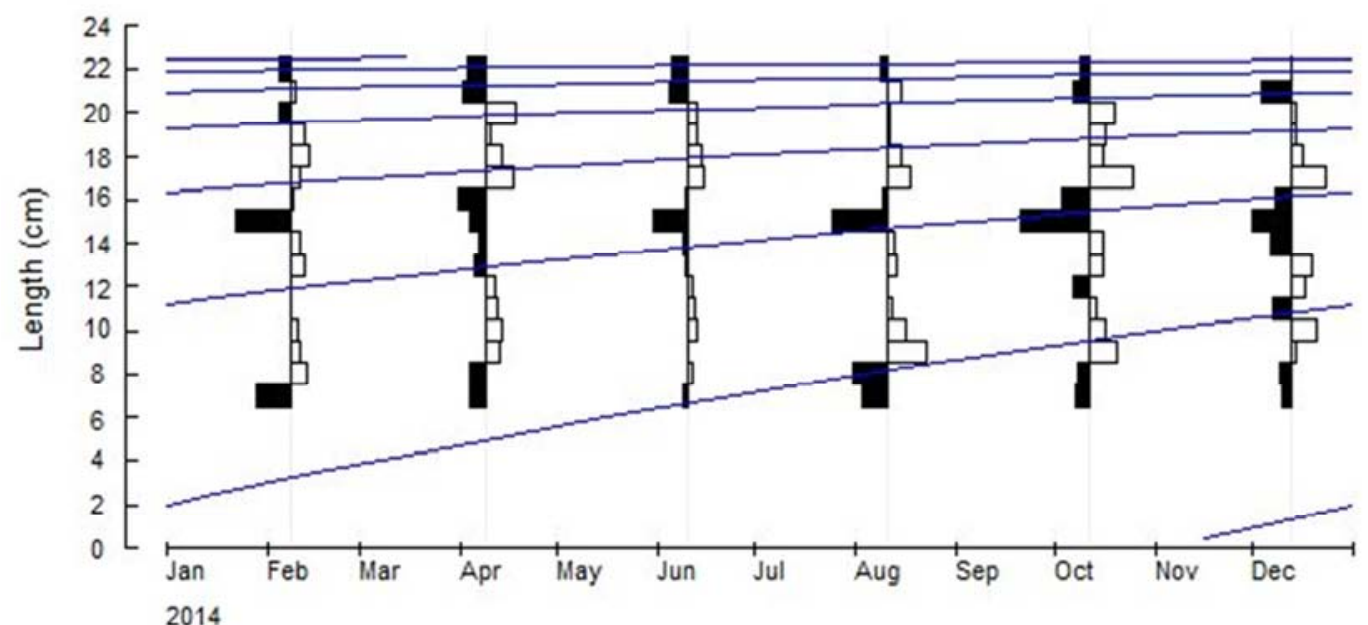

b

Figure 4. Length-frequency distribution data and the growth curves estimated using ELEFAN for P. maculatus in the Karachi coast of Pakistan, a \& $b$ for 2012 and 2014 respectively.

Because $\bar{L}_{L^{\prime}}=6.744 \mathrm{~cm}$ for 2012 and $\bar{L}_{L^{\prime}}=17.234$ for 2014 , $L^{\prime}=15 \mathrm{~cm}$ (same for both years), the total annual mortality " $Z$ ' estimated by the Beverton and Holt's method is 3.64 and 2.62 per year in 2012 and 2014 respectively.

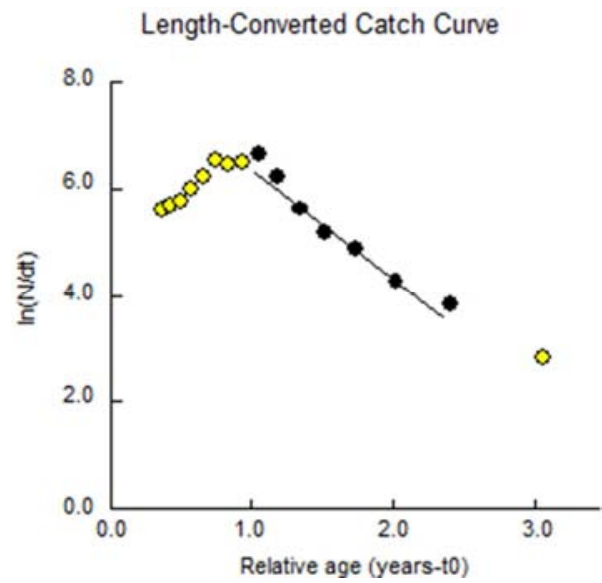

a

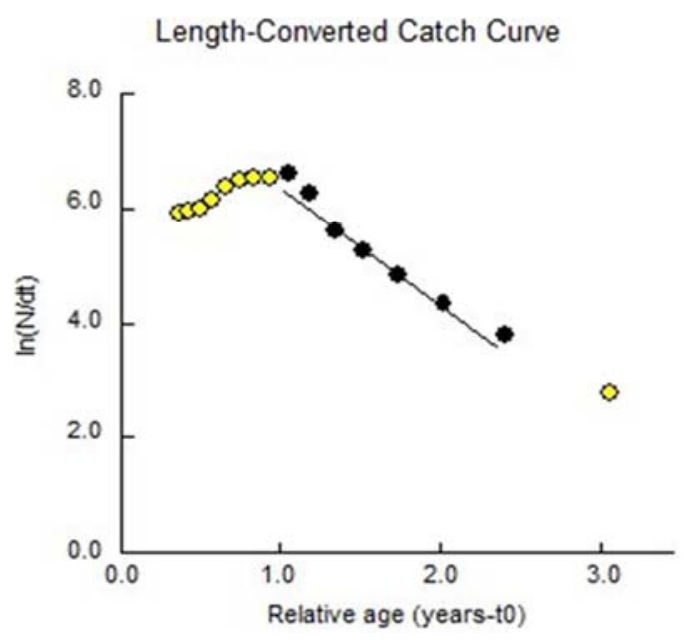

b

Figure 5. A length-converted catch curve for P. maculatus in Karachi for the pooled data $\left(L_{\infty}=23.10 \mathrm{~cm}\right.$ and $k=1.00$ year $\left.^{-1}\right),(a)$ and (b) for 2012 and 2014 respectively. 
Yield-per-recruit contour maps are shown in Figure 5, for the $P$. maculatus was analyzed by the model of $Y / R$ with the knife edge selection in FiSAT-II. When $\mathrm{tc}=1$ the $\mathrm{F}_{\max }=1 \mathrm{yr}^{-}{ }^{-}$. Since the present age at the initially capture was almost 1 year and $F_{\text {current }}$ was 0.9 year $^{-1}$ and 0.77 year $^{-1}$ for 2012 and 2014 respectively, the $\mathrm{F}_{\text {current }}$ was smaller than $\mathrm{F}_{\max }$ indicating the stock of $P$. maculatus was under exploitation state. The BRPs was equal to $F_{\text {opt }}$ was equivalent to $M(1.16)$ year $^{-1}$ for 2012 and $M(1.30)$ year ${ }^{-1}$ for 2014 . The $F_{\text {current }}$ was below the biological reference point target benchmark.
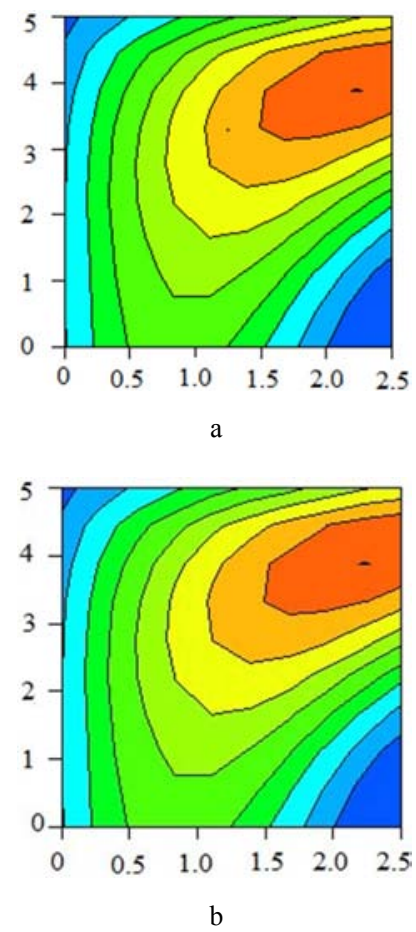

Figure 6. Yield per recruit contour map of P. maculatus from Pakistani waters during (a) 2012 and (b) 2014. X-axis is fishing mortality; $y$-axis is the age at first capture.

The von Bertalanffy of $L_{\infty}$ and $K$ were used to the estimate the GPI (growth performance indices) to be 2.408 for 2012 and 2.483 for 2014, based on length frequency data for $P$. maculatus from Karachi coast of Pakistan. Cohort analysis to output graphics for LVPA was done by FiSAT (Figure 7a \& b). The length of the high $F$ was seen in $22 \mathrm{~cm}$ (TL).

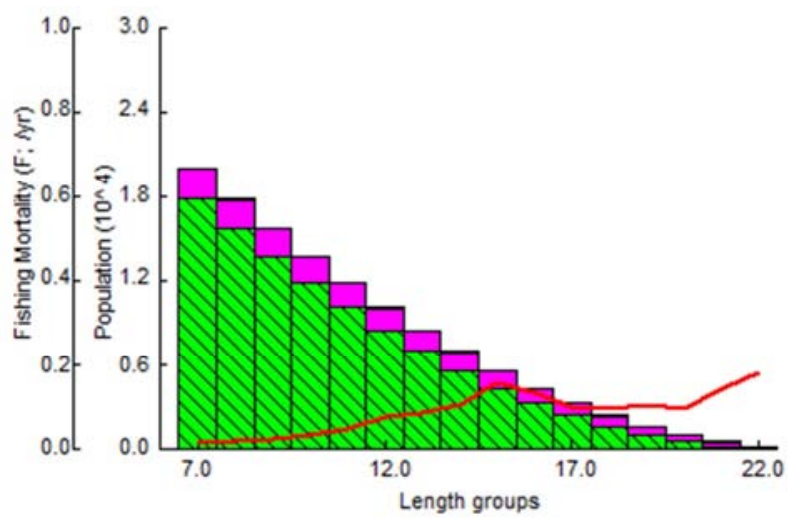

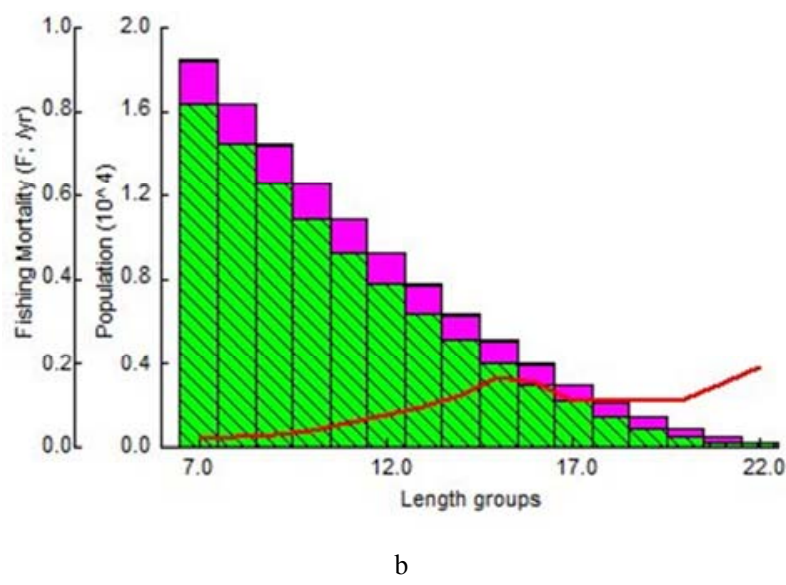

Figure 7. Length-structured virtual population analysis (VPA) of $P$. maculatus from Pakistani waters during (a) 2012 and (b) 2014.

\section{Discussion}

The length-weight relationship is considered to be a useful measurement which makes easy for the estimations of metamorphosis, maturity, gonad and rate of feeding of fish by Le Cren [16], which is deliberated as a significant parameter in fishery biology and fish stock assessment [15]. In the present study, the value of the slope " $b$ " of $P$. maculatus was estimated to be $2.532\left(R^{2}=0.978\right)$ in 2012 and $2.560\left(R^{2}=0.979\right)$ in 2014 from the Karachi coast of Pakistan, which indicates the negative allometric growth [17].

The estimated value of slope $b$ was compared with the results obtained from the other areas of the world of the same species (Table 1), the $b$ values were 2.915 for male, 2.871 for female and 2.901 for combined sexes from the Central Kerala [18]. It was 3.70 from the Korangi Creek and 2.79 from the Miani Hor Pakistan [19]. The above values were greater than the present study. The $b$ value (Both sexes) was 2.62 from the Gulf of Aden [21]. The $b$ value of both sexes was 2.569 from Indonesian waters [20] which was very close to the present work.

Table 1. Comparison of value $b$ of P. maculatus with previous studies from different areas of the world to present study from Karachi coast, Pakistani during 2012 and 2014.

\begin{tabular}{lll}
\hline Location & Slope "b" & Sources \\
\hline Central Kerala (Male) & 2.915 & Mandy, 2015 \\
(Female) & 2.871 & \\
(Combined) & 2.901 & \\
Gulf of Aden & 2.262 & Edwards and Shaher, 1991 \\
Korangi Creek, Pakistan & 3.7 & Ahmed and Abbas, 2000 \\
Miani Hor, Pakistan & 2.79 & \\
Indonesian waters & 2.569 & Pauly and Martosubroto, 1996 \\
Karachi coast, Pakistan & 2.532 in 2012 & Present study \\
& 2.56 in 2014 & \\
\hline
\end{tabular}

Growth is defined as the addition of material to that which is already organized into a living pattern. VBGF parameters $L_{\infty}, K$ and $t_{0}$ were estimated from the length frequency data of P. maculatus during 2012 and 2014 from the Karachi coast of Pakistan and comparison with the earlier work done from the other areas (Table 2). 
Table 2. Comparison of growth parameters of P. maculatus from present study with those from previous studies.

\begin{tabular}{lllll}
\hline Location & $\mathbf{L}_{\infty}$ & $\mathbf{K}$ & $\mathbf{t}_{\mathbf{0}}$ & \\
\hline Gulf of Aden & $70.5 \mathrm{~cm}$ & 0.16 & 0.019 & Sources \\
Karachi coast, Pakistan & 23.1 & 0.48 & -0.366 & Edwards and Shaher, 1991 \\
& 23.1 & 0.57 & -0.306 & in 2012 \\
\hline
\end{tabular}

$L_{\infty}=$ asymptotic length (mm-TL); $K=$ growth rate $y e a r^{-1} ; \varphi^{\prime}=$ growth performance index; $t_{0}=$ hypothetical age at which length of the fish is equal to zero

In this study the ELEFAN-I in the FiSAT-II computer software package was used to estimate the VBGF parameters $\left(L_{\infty}\right.$ and $\left.K\right)$. $L_{\infty}$ was $23.10 \mathrm{~cm}, K$ was 0.480 in 2012 and $L_{\infty}$ was $23.10 \mathrm{~cm}, K$ was 0.570 in 2014. The asymptotic length $L_{\infty}$ was estimated to be $70.5 \mathrm{~cm}$ from Gulf of Aden [21] which is greater while the growth rate $K$ was 0.16 which is lower than the current investigation. In the present study $t_{0}$ values were calculated as -0.3659 for 2012 and -0.3061 for 2014 . The $t_{0}=0.019$ from the Gulf of Aden [21] is greater than the present study $t_{0}=-0.1708$. We believe that Edwards and Shaher [21] work may be wrong because the value of $t_{0}$ in VBGF is usually negative.

The present study used length-converted catch curve analysis for estimation of the mortality rate of $P$. maculatus during 2012 and 2014, using input values of the VBGF growth parameter given above from the Karachi coast of Pakistan. The estimated mortality rates were compared with earlier studies from the same species, but different countries of the world (Table 3 ).

The mortality values in this study $Z=2.06$ years $^{-1}, M=1.16$ years $^{-1}$ and $F=0.9$ years $^{-1}$ were, in 2012 while $2.07,1.30$ and 0.77 years $^{-1}$ respectively in 2014 . The exploitation ratio $(E)$ was calculated from $F / Z=0.43$ and 0.32 for 2012 and 2014 respectively. The $Z$ was $0.35 M$ was 0.43 from the Gulf of Aden Edwards and Shaher, [21] which were very lower than the present study.

Table 3. Mortality rates of P. maculatus from the Karachi coast of Pakistan were compared with the other studies from different areas.

\begin{tabular}{lllll}
\hline Area & Z & M & & Sources \\
\hline Gulf of Aden & 0.35 & 0.43 & Edwards and Shaher, 1991 \\
Karachi coast, Pakistan & 2.06 & 1.16 & in 2012 & present study \\
\hline
\end{tabular}

$Z=$ total mortality, $M=$ natural mortality.

However, we suspect that Edwards and Shaher [21] estimations may be wrong because the total mortality rate must be larger than the natural mortality rate. The different values from different areas of the world were because of unfavorable environmental conditions or commercial demand [22]. Predation is a big cause of natural mortality for $P$. maculatus $[23,24]$. However, in the present study, the fishing mortalities (0.18 and 0.19) in 2012 and 2014 respectively, are lower than natural mortality (1.88) which indicate that the stock of $P$. maculatus is well managed in Pakistan.

The total annual mortality estimated by the Beverton and Holt's method is: $Z=3.64$ per year in 2012 and 2.62 per year in 2014, which is greater than the results of catch curve analysis. Because the length converted catch curve analysis method is more commonly used, we chose $Z=2.06$ for 2012 and $Z=2.07$ for 2014 as our final results.

The Gulland [25] criterion of biological reference points (BRPs) was estimated at the optimum fishing mortality rate of 1.88 year $^{-1}$ for both years. The $Y / R$ analysis (Figure 5) indicated that when $t_{c}=1$ and $F_{\max }=1$ (same for both years) and $F_{\text {current }}=0.9$ years $^{-1}$ and 0.77 years $^{-1}$ for 2012 and 2014 respectively. These values showed that the currently $F$ is safe.

The growth performance index $\left(\varphi^{\prime}\right)$ is usually estimated from $L_{\infty}$ and $K$. If the value is higher it indicates faster and larger growth of the fish [12] and [14]. In this study the growth performance index is 2.727. Ecological and environmental changes may cause the differences among the values of the growth performance index [26].

\section{Conclusion}

The conclusion, from the above values we can conclude that the P. maculatus fishery is safe in the Karachi coast of Pakistan. Because of limited available information with those from other studies, i.e. what ecological/biological process contributes to such differences, considering spatial differences and/or temporal differences can influence the life history parameter estimates.

\section{Acknowledgements}

The first author acknowledges the CSC (Chinese Scholarship Council) for funding his $\mathrm{PhD}$ Degree and College of Fisheries, Ocean University of China, Qingdao, China for facilitation.

\section{References}

[1] FAO., 2009. Fishery and Aquaculture Country Profile. FAO Fisheries Department, Rome, 1-18.

[2] Nazir, K., M. Yongtong, K. Hussain, M. A. Kalhoro and S. Kartika, 2014. A study on Exports of Fish and Fish products and their Role in Economic Growth of Pakistan. International Journal of Marine Science, 4. doi: 10.5376/ijms.2014.04.0064. 
[3] Bianchi, G., 1985. FAO species identification sheets for fishery purposes. Field guide to the commercial marine and brackish water species of Pakistan. Prepared with the support of PAK/77/033/ and FAO (FIRM) Regular Programme. FAO, Rome. 70 p.

[4] Fishbase., 2016. http://www.fishbase.org/summary/FamilySummary.php?ID=3 27 (Accessed on 29 June 2016).

[5] FAO., 2001. Food and Agriculture Organization of the United Nations. The living marine resources of the western central Pacific. Bony fishes part 3 (Menidae to Pomacentridae). FAO, Rome, Italy.

[6] Khan, M. A., 2004. Amtyaz. Studies on the Fecundity and sex ratio of the Saddle Grunt Fish, Pomadasys maculatum (BLOCH, 1797) (Family: Pomadasyidae) From Karachi Coast Pakistan. International Journal of biology and biotechnology, 1 (1), pp. 111-115.

[7] Amtyaz, K. M., Khan, M. Z. and Hashmi, M. U. A., 2014. The Sex Ratio, Gonadosomatic Index \& Stages of Gonadal Development of Saddle Grunt fish, Pomadasys maculatum (Bloch, 1797) of Karachi Coast, Pakistan. Canadian Journal of Pure and Applied Sciences, 8 (1), pp. 2721-2726.

[8] Gayanilo, F. C., P. Sparre and D. Pauly, 2003. FAO-ICLARM Stock Assessment Tool (FiSAT II) User's Guide, FAO Computerized Information Series (Fisheries). No. 8, Rome, FAO, $266 \mathrm{pp}$

[9] Haddon, M., 2011. Modeling and quantitative methods in fisheries. Second edition. London: Chapman \& Hall/CRC press, 449.

[10] Pauly, D., 1983. Some simple methods for the assessment of tropical fish stocks (No. 234). Food and Agriculture Organization, doi: 10.1002/iroh.19840690521.

[11] Beverton, R. J. H. and S. J. Holt, 1956. A review of methods for estimating mortality rates in exploited fish populations, with special reference to sources of bias in catch sampling. Rapp. P.-v. Réun. Cons. Int. Explor. Mer., 140

[12] Sparre, P. and S. C. Venema, 1998. Introduction to tropical fish stock assessment Part 1: Manual. FAO Fisheries Technical Report, 306/1, Rev 2. Rome: FAO, 407.

[13] Pitcher, T. J. and P. J. B. Hart, 1982. Fisheries Ecology. Croom Helm, London, 250-292. doi: 10.1002/iroh.19830680215.

[14] Pauly, D. and J. I. Munro, 1984. Once more on the comparison of growth in fish and invertebrates. FishByte, 2: 21-23. doi: $10.1007 / \mathrm{bf00393260.}$

[15] Abdurahiman, K. P., T. Harishnayak, P. U. Zacharia and K. S. Mohamed, 2004. Length-weight relationship of commercially important marine fishes and shellfishes of the Southern Coast of Karnataka, India. NAGA, WorldFish Center Quarterly, 27: $9-14$.

[16] Le-Cren, C. P., 1951. Length-weight relationship and seasonal cycle in gonad weight and condition in the Perch (Percafluviatilis). The Journal of Animal Ecology, 20: 201219. doi: $10.2307 / 1540$.

[17] King, M., 1995. Fisheries biology, assessment and management. (Blackwell Science Ltd. London, UK) 341.

[18] Mandy. T. J., 2015. Systematics and bionomics of edible perches of central Kerala.

[19] Ahmed, M. and G. Abbas, 2000. Growth Parameters ofthe Finfish and Shellfish Juveniles in the Tidal Waters of Bhanbhore, Korangi Creek and Miani Hor Lagoon. Pakistan Journal Zoology, 32: 21-26.

[20] Pawly, D. and P. Martosubroto, 1996. Baseline Studies of Biodiversity: fish Resources of Western Indonesia. 173 p. doi: $10.1086 / 420249$

[21] Edwards, R. R. C. and S. Shaher, 1991. The biometrics of marine fishes from the Gulf of Aden. Fishbyte, 9: 27-29.

[22] Nikolskii, G. V., 1969. Theory of fish population dynamics as the background for rational exploitation and management of fishery resources. Translated from the Russian edition (Moscow, 1965) by J. E. S. Bradley. R. Jones, Ed. Oliver and Boyd, Edinburgh, 324. doi: 10.1126/science.169.3943.363.

[23] Brandt, S. B., D. M. Mason, D. B. Macneill, T. Coates, and J. E. Gannon, 1987. Predation by alewives on larvae of yellow perch in Lake Ontario. Transactions of the American Fisheries Society, 116: 641-645. doi: 10.1577/1548-8659 (1987)116<641:pbaolo >2.0.co;2.

[24] Laevastu, T. and F. Favorite, 1988. Fishing and stock fluctuations. Farnham, Surrey, Fishing News Books, London, UK, pp. 240.

[25] Gulland, J. A., 1969. Manual of methods for fish stock assessment Part 1. Fish population analysis. Fishery resources and exploitation division, FAO, Rome, p 154.

[26] Devaraj, M., 1981. Age and growth of the three species of Seerfishes, Scombermorus commerson, S. guttatus, $S$. lineolatus. Indian Journal Fisheries, 28: 104-127.

[27] Froese, R., 2006. Cube law, condition factor and weightlength relationships: history, meta - analysis and recommendations. Journal of applied ichthyology, 22: 241253. doi: $10.1111 / \mathrm{j} .1439-0426.2006 .00805$. x. 